\title{
Effect of antioxidants in a liposomal form containing organic iodine of the blood serum biochemical composition and the structure of muscle tissue formation of young rabbits
}

\author{
$D$ Zubochenko ${ }^{1}, V$ Pashtetsky $^{1}, P$ Ostapchuk $^{1,{ }^{*}}, T$ Kuevda $^{1}$, Ye Zyablitskaya ${ }^{2}, T$ Makalish $^{2}$, \\ and $A$ Kopylova ${ }^{2}$ \\ ${ }^{1}$ Research Institute of Agriculture of Crimea, 150, Kievskaya Street, Simferopol, Republic of Crimea, \\ 295493, Russia \\ ${ }^{2}$ V. I. Vernadsky Crimean Federal University, 5/7, Lenin Boulevard, Simferopol, 295051, Russia
}

\begin{abstract}
The study of the effect of antioxidants containing organic iodine on the formation of the enteral environment of California young rabbits is described in the article. A significant increase in the level of thyroxine in the experimental groups was in the 2 nd by $6.7 \%$ and in the $3 \mathrm{rd}$ by $8.9 \%(\mathrm{P}<0.05)$. In the third group, there was a significant tendency to increase the total protein in the blood serum: compared with the control, it increased by 3.39 units $(\mathrm{P}<0.05)$. This trend continues in the level of albumin at 3.58 units. $(\mathrm{P}<0.05)$. There was a significant increase in creatinine in young rabbits of both experimental groups by 20.51-28.89 units $(\mathrm{P}<0.05)$. There was a significant excess of iodine content in the meat of rabbits of group 2 by $81.0 \mathrm{mcg}(\mathrm{P}<0.05)$, and in animals of group 3-by $234.1 \%(\mathrm{P}<0.05)$. There was an increase in the number of muscle fibers in both experimental groups by 68.0 and $78.0 \%(\mathrm{P}<0.05-0.01)$. The diameter of the muscle fiber of experimental animals was significantly lower by 13.1 and $17.3 \%(\mathrm{P}<0.05)$. The animals of the experimental groups formed meat with a more delicate structure and an increased content of valuable parts-muscle and fat tissue.
\end{abstract}

\section{Introduction}

Antioxidant vitality has been proven to have positive effects in rabbit breeding [1-2]. Antioxidant effects lead to improved animal health and increased growth of target tissues [3]. Toxins and fluctuations in ambient temperature lead to pathological changes: tissues are damaged; blood parameters change [2]. A positive effect on blood parameters in rabbits when using antioxidants has been proved [4]. Adverse factors contribute to an increase in free radicals, which can cause irreversible damage to cells [5].

The search, characterization, and application of natural antioxidants remain the focus of numerous research groups around the world. Natural antioxidants are now one of the most popular topics in the field of food and agriculture [6]. According to one theory, it is

* Corresponding author: pavelos76@mail.ru 
believed that the antioxidant properties of plants are developed in the course of evolution based on photosynthetic activity. Therefore, each species, subspecies, and variety of plants can be an object for evaluating the antioxidant potential [6]. An ideal antioxidant should be easily absorbed by the body and prevent the formation of free radicals at physiologically significant levels [7].

Useful properties of vegetable extracts in animal husbandry and poultry farming have recently been used more often $[8,9]$ due to low toxicity, pharmacological activity and economic viability [10-11]. Thus, feed additives of natural antioxidants can increase the efficiency of growing animals and poultry without compromising the quality of the products.

The use of the proper form of antioxidants remains an urgent problem. Antioxidants in their pure form, due to their low degree of solubility, are practically unable to overcome the barriers of cell membranes. The liposomal form will allow equally effective transportation of vital compounds in sufficient concentrations: water-soluble, fat-soluble, combinations of various antioxidants, etc. [12]. This form is widely used in medical practice [13].

Liposomal antioxidant action in poultry farming has been established to be effective [14-15]. Thus, the use of liposomal forms of antioxidants is an important part of further agroecological research in the field of agricultural production. These data will be aimed at ensuring environmental well-being in the course of further development of technologies in the agro-industrial complex [16].

The study of the effect of antioxidants in a liposomal form containing organic iodine on the formation of the biochemical composition of the blood serum of Californian young rabbits and the structure of muscle tissue has become the main aim of the research.

\section{Material and methods of research}

Research material: young rabbits of the California breed. Conditions for keeping animals: housing in cages. Feeding (main diet) - ready-made full-ration feed mixes to meet nutrient requirements. The young animals were weaned from the females rabbits at the age of $41^{\text {st }}$ day. Young animals were housed in cages (4 young rabbits per cage). Young rabbits were distributed into three treatment groups: $1^{\text {st }}$ (control group) - main diet (MD); $2^{\text {nd }}$ (experimental group) - MD + "Polysol omega-3" (a liposomal form of antioxidants containing organic iodine of algae Laminaria digitate obtained from the White sea) at a rate of $250 \mathrm{~g}$ per ton of feed mixture in the form of granules; $3^{\text {rd }}$ (experimental group) - MD + "Polysol omega-3" (a liposomal form of antioxidants containing organic iodine of algae Cystoseira barbata obtained from the Black sea) at a rate of $250 \mathrm{~g}$ per ton of feed mixture in the form of granules. Each group consisted of 20 young rabbits. Weighing of young rabbits was carried out individually in the morning before feeding: at birth, at weaning, on the $60^{\text {th }}$ and $90^{\text {th }}$ days. The experimental animals were offered feed according to physiological norms.

Before slaughter, blood samples were collected from the ear vein from the rabbits to determine total protein, albumin, glucose, alanine aminotransferase, asparaginaminotransferase, alkaline phosphatase, creatinine, urea, bilirubin, a-amylase, calcium, phosphorus. The studies were conducted on three animals from each group. The research was carried out on a biochemical analyzer Vitalab Flexor E. Thyroxine $\left(\mathrm{T}_{4}\right)$, triiodothyronine $\left(\mathrm{T}_{3}\right)$ and thyroid-stimulating hormone (TSH) was carried out on a biochemical analyzer StatFax 3200.

Determination of nitrogen by burning a suspension of concentrated sulfuric acid using a catalyst is a copper (II) sulfate. Organic nitrogen passes into ammonium ions and is leached. Distillation of the released ammonia into an excess boric acid solution occurs. Titration with hydrochloric acid to determine the amount of boric acidbound ammonia. 
Calculation of the mass fraction of nitrogen in the product sample, based on the amount of formed ammonium. Determination of calcium by titrimetric method by forming a lowdissociated complex compound of calcium with a disodium salt of Ethylenediamine-N', N', N', N'-tetraacetic acid (Trilon B) in an alkaline medium and determining the equivalent point during titration using metal indicators. Determination of magnesium by flame atomic absorption spectrometry. Determination of iodine in meat was carried out by voltammetric method. Determination of selenium was carried out by wet burning of the sample with a mixture of nitric and perchloric acids and reduction of hexavalent selenium to $\mathrm{Se}^{+4}$ by the action of hydrochloric acid. The complex of selenic acid with 2,3-diaminophthalenepiazoselenol is determined by the amount of fluorescence. This value is proportional to the selenium content in the sample. Determination of cobalt by electrothermal atomic absorption spectrometry. Determination of copper was carried out by inversionvoltammetric measurement of this element concentration.

Histological studies of the muscle tissue of young rabbits were carried out in the histological laboratory of the Center for collective use "Molecular Biology" of the Medical Academy named after S.I. Georgievsky on samples taken from the thigh of the left hind paw of control and experimental animals. The material for histological studies was fixed in $10 \%$ buffered formalin for 24 hours; then it was dehydrated and impregnated with paraffin in a LOGOS microwave Mielstone histoprocessor. From the manufactured paraffin blocks, serial sections with a thickness of 4 microns were made. These blocks were stained with hematoxylin and eosin. Using DM2000 microscope, sections were viewed and photographed with $10^{*}$ and $40 *$ lenses. Obtained photographs processed in the ImageJ was used to measure morphometric parameters. The number of muscle bundles in $100 \mathrm{~mm}^{2}$, their diameter, the ratio of muscle and connective tissue in the field of view, and the thickness of the endomysium and perimysium were measured. Obtained values were statistically processed in Statistica 10. Portable using nonparametric methods and descriptive statistics methods. The differences significant if the probability of error was less than $0.05,0.01$ and 0.001 were considered.

\section{Research results}

Visual observations showed that the studied feed additive did not have any negative effect on the body of young rabbits. During the experiment, all animals were active and consumed feed well. Safety calculations revealed the positive effect of "Polysol omega-3" on the safety of rabbits (Table 1).

Table 1. Young rabbits safety in the experiment.

\begin{tabular}{|c|c|c|c|}
\hline Indicator & $1^{\text {st }}$ group & $2^{\text {nd }}$ group & $3^{\text {rd }}$ group \\
\hline Number of heads & 25 & 25 & 25 \\
\hline Cases of case in the experiment, heads & 5 & 3 & 4 \\
\hline Safety, $\%$ & 80.0 & 88.0 & 84.0 \\
\hline
\end{tabular}

Cases of young animal deaths were recorded in all studied groups. Young rabbits from the experimental groups were less susceptible to various diseases. Safety of rabbits in the control group was $80 \%$; in the second experimental group - $88.0 \%$, which is $8.0 \%$ more than in the control one. In the third experimental group, receiving feed additive "Polysol omega 3" based on the Cystoseira barbata obtained from the Black sea, rabbits' safety reached $84.0 \%$, which is $4 \%$ higher than in the control group.

According to table 2, it can be concluded that the inclusion of the studied additives in the diet of the rabbits from the experimental groups had a positive effect on the dynamics of live weight growth. 
Table 2. Dynamics of rabbits' live weight growth, $\mathrm{X} \pm \mathrm{S} \mathrm{X}$.

\begin{tabular}{|c|c|c|c|}
\hline Indicator & $1^{\text {st }}$ group & $2^{\text {nd }}$ group & $3^{\text {rd }}$ group \\
\hline $\begin{array}{c}\text { Live weight at the beginning of the experiment }(41 \\
\text { days), } g\end{array}$ & $929.0 \pm 38.46$ & $1035.38 \pm 51.24$ & $910.67 \pm 25.28$ \\
\hline $\begin{array}{c}\text { Live weight at the age of 92 days (end of the } \\
\text { experiment), } g\end{array}$ & $2364.6 \pm 35.83$ & $2396.0 \pm 47.29$ & $2488.53 \pm 37.3$ \\
\hline As a percentage of the control group & 100.0 & 101.3 & 105.2 \\
\hline Absolute growth, $g$ & $1435.6 \pm 47.8$ & $1361.6 \pm 56.91$ & $1577.8 \pm 46.81$ \\
\hline As a percentage of the control group & 100.0 & 94.8 & 109.8 \\
\hline Average daily growth, g & $28.15 \pm 0.94$ & $26.7 \pm 1.21$ & $30.9 \pm 0.89$ \\
\hline As a percentage of the control group & 100.0 & 94.8 & 109.7 \\
\hline
\end{tabular}

The live weight of young rabbits from all groups was approximately at the same level $910.0-1035.0 \mathrm{~g}$ at the beginning of the experiment. Young rabbits in the control group were inferior in terms of live weight to animals in the experimental groups by the end of the experiment. The largest increase in live weight was observed in young rabbits of the third experimental group ("Polysol omega 3" based on Cystoseira brabata from the Black Sea) $1577.8 \mathrm{~g}$, which is $9.8 \%$ more than in the control group. The average live weight of young rabbits in the third group was $2488.5 \mathrm{~g}$, which is $5.2 \%$ more than that of in the control one. At the same time, the absolute growth rate of the young animals of the second experimental group was $5.2 \%$ lower than in the control one and amounted to $1361.6 \mathrm{~g}$ compared to $1435.6 \mathrm{~g}$ in the control group. A similar situation was in terms of absolute average daily weight gain. In the second group, the absolute increase compared to the control one was by $5.2 \%$ lower; in the $3^{\text {rd }}$ group it was $9.7 \%$ higher.

Thyroxine $\left(\mathrm{T}_{4}\right)$ and triiodothyronine $\left(\mathrm{T}_{3}\right)$ are thyroid hormones. They are produced and released by the thyroid gland and are catalysts for the formation and release of energy, controlling the synthesis of cellular proteins, in particular, enzymes [17]. Thyroidstimulating hormone (TSH) is a glycoprotein synthesized by the pituitary gland, in the synthesis of which thyrotropin-releasing hormone is present as a catalyst [18].

The relationship between thyroid hormones and thyroid-stimulating hormone was noted: logarithmic dependence of the production of TSH and bound $\mathrm{T}_{4}$ in humans is noted. In this case, it is established that a slight decrease in T4 level increases the values of TSH [19]. However, TSH and $\mathrm{T}_{3}$ levels are determined by $64 \%$. At the same time, there were no hereditary correlations between the content of TSH and human thyroid hormones [20-22].

Table 3 shows data on the content of thyroid hormones in the blood serum of rabbits of the studied groups. 
Table 3. Thyroid hormones in young rabbits of the studied groups, $X \pm S_{X}(n=9)$.

\begin{tabular}{|c|c|c|c|}
\hline & \multicolumn{3}{|c|}{$\mathrm{T}_{4}, \mathrm{nmol} / \mathrm{L}$} \\
\hline $\mathrm{X} \pm \mathrm{S}_{\mathrm{X}}$ & $13.94 \pm 0.47$ & $14.87 \pm 0.28$ & $15.18 \pm 0.39 *$ \\
\hline \multirow[t]{2}{*}{$\mathrm{C}_{\mathrm{v}}, \%$} & 10.02 & 5.58 & 7.74 \\
\hline & \multicolumn{3}{|c|}{$\mathrm{T}_{3}, \mathrm{pmol} / \mathrm{L}$} \\
\hline $\mathrm{X} \pm \mathrm{S}_{\mathrm{X}}$ & $3.77 \pm 0.17$ & $3.52 \pm 0.07$ & $3.88 \pm 0.09$ \\
\hline \multirow[t]{2}{*}{$\mathrm{C}_{\mathrm{v}}, \%$} & 13.29 & 5.81 & 6.60 \\
\hline & \multicolumn{3}{|c|}{ TSH, mU/L } \\
\hline $\mathrm{X} \pm \mathrm{S}_{\mathrm{X}}$ & $0.30 \pm 0.01$ & $0.31 \pm 0.01$ & $0,32 \pm 0.01 *$ \\
\hline $\mathrm{C}_{\mathrm{v}}, \%$ & 6.11 & 11.46 & 7.85 \\
\hline Here and fu & $\begin{array}{l}: \text { differenc } \\
-\mathrm{p}<0.05\end{array}$ & $\begin{array}{l}\text { ant with the } \\
* * *-p<0.0\end{array}$ & statistical \\
\hline
\end{tabular}

The content of thyroxine in the experimental groups exceeds the same in the control one: $2^{\text {nd }}-$ by $6.7 \%$; $3^{\text {rd }}$ - by $8.9 \%(p<0.05)$. According to the concentration of triiodothyronine, the difference between the groups varies slightly - from $3.52 \mathrm{pmol} / 1$ in the $2^{\text {nd }}$ group to $3.88 \mathrm{pmol} / 1$ in the $3^{\text {rd }}$. The content of thyroid-stimulating hormone in the $2^{\text {nd }}$ group prevails over the control group by $4.4 \%$, and the $3^{\text {rd }}$ - by $8.3 \%(p<0.05)$ (table 3$)$.

Table 4 shows correlations within groups between indicators of thyroid hormone content. There was a significant positive relationship between T4 and T3 $(0.60 \pm 0.30$, $\mathrm{p}<0.05$ ).

Biochemical parameters of blood serum of young rabbits on the background of feeding antioxidants in liposomal form with organic iodine content are set out in table 5 .

Table 4. Correlation between indicators of thyroid hormone content within the study groups $(n=9)$.

\begin{tabular}{|c|c|c|}
\hline \multicolumn{3}{|c|}{$1^{\text {st }}$ group } \\
\hline & $\mathrm{T}_{4}$ & $\mathrm{~T}_{3}$ \\
\hline $\mathrm{T}_{3}$ & $0,34 \pm 0,36$ & - \\
\hline TSH & $0,20 \pm 0,37$ & $0,51 \pm 0,33$ \\
\hline \multicolumn{3}{|c|}{$2^{\text {nd }}$ group } \\
\hline $\mathrm{T}_{3}$ & $0,60 \pm 0,30^{*}$ & - \\
\hline $\mathrm{TSH}$ & $0,48 \pm 0,33$ & $-0,01 \pm 0,38$ \\
\hline $\mathrm{T}_{3}$ & $3^{\text {rd }}$ group & - \\
\hline TSH & $-0,07 \pm 0,96$ & $-0,04 \pm 1,57$ \\
\hline
\end{tabular}


Table 5. Biochemical parameters of blood serum of young rabbits on the background of feeding antioxidants in liposomal form with organic iodine content, $\mathrm{X} \pm \mathrm{S}_{\mathrm{X}}$.

\begin{tabular}{|c|c|c|c|c|}
\hline & $\begin{array}{c}\text { Unit } \\
\text { measurement }\end{array}$ & $1^{\text {st }}$ group & $2^{\text {nd }}$ group & $3^{\text {rd }}$ group \\
\hline Total protein & $\mathrm{g} / \mathrm{L}$ & $45.21 \pm 0.72$ & $46.23 \pm 0.54$ & $48.60 \pm 1.16^{*}$ \\
\hline Albumin & $\mathrm{g} / \mathrm{L}$ & $42.80 \pm 0.29$ & $44.13 \pm 0.44^{*}$ & $46.38 \pm 0.99^{* *}$ \\
\hline Glucose & $\mathrm{mmol} / \mathrm{L}$ & $5.13 \pm 0.33$ & $4.75 \pm 0.19$ & $4.50 \pm 0.27$ \\
\hline Alanine aminotransferase & $\mathrm{U} / \mathrm{L}$ & $56.48 \pm 5.69$ & $71.78 \pm 4.77^{*}$ & $62.02 \pm 7.60$ \\
\hline Aspartate aminotransferase & $\mathrm{U} / \mathrm{L}$ & $80.84 \pm 11.43^{*}$ & $78.17 \pm 8.92$ & $79.15 \pm 9.34$ \\
\hline Total bilirubin & $\mathrm{gmol} / \mathrm{L}$ & $0.26 \pm 0.05$ & $0.13 \pm 0.03$ & $0.24 \pm 0.02$ \\
\hline Direct bilirubin & $\mathrm{gmol} / \mathrm{L}$ & $0.15 \pm 0.04$ & $0.48 \pm 0.04 *$ & $0.40 \pm 0.05^{*}$ \\
\hline Urease & $\mathrm{mmol} / \mathrm{L}$ & $7.34 \pm 0.69$ & $8.17 \pm 0.77^{*}$ & $9.12 \pm 0.93$ \\
\hline Alpha-amylase & $\mathrm{U} / \mathrm{L}$ & $236.88 \pm 13.30$ & $257.58 \pm 19.39$ & $288.67 \pm 23.68$ \\
\hline Alkaline phosphatase & $\mathrm{U} / \mathrm{L}$ & $153.13 \pm 16.42$ & $132.00 \pm 7.60$ & $127.50 \pm 6.53$ \\
\hline Phosphorus & $\mathrm{mmol} / \mathrm{L}$ & $2.30 \pm 0.07$ & $2.32 \pm 0.04$ & $2.91 \pm 0.06^{*}$ \\
\hline Creatinine & $\mathrm{gmol} / \mathrm{L}$ & $59.96 \pm 1.68$ & $80.47 \pm 2.07^{*}$ & $88.85 \pm 2.54^{*}$ \\
\hline Potassium & $\mathrm{mmol} / \mathrm{L}$ & $5.09 \pm 0.06$ & $5.85 \pm 0.10^{*}$ & $5.25 \pm 0.05$ \\
\hline
\end{tabular}

The tendency to increase the total protein in blood serum in young rabbits of experimental groups increases. In the third group, this trend is reliable: in comparison with the control, it increases by 3.39 units. The increase in total protein was due to an increase in albumin levels by 3.58 units.

No fundamental regularities were found in the content of liver enzymes. Direct bilirubin is characterized by an increased content in the experimental groups by $0.25-0.33$ units. There was an increase in creatinine in young rabbits of both experimental groups by 20.51 28.89 units.

Table 6 shows the content of certain micro- and macronutrients in rabbit meat in the experiment.

Nitrogen is contained in the protein compounds of the body. A significant advantage in nitrogen content by $0.15 \mathrm{mg} / \mathrm{kg}(4.2 \%)(\mathrm{p}<0.05)$ was noted in animals of the $2^{\text {nd }}$ experimental group. There was a significant excess of iodine content in meat in the $2^{\text {nd }}$ group of rabbits by $81.0 \mathrm{mcg}(551.0 \%)$ and in animals of $3^{\text {rd }}$ group by $34.45 \mathrm{mcg}(234.1$ \%) (table 6).

The young rabbits' muscles consist of striated muscle fibers united in bundles histologically level. In both groups, the transverse striation is well expressed, which indicates the functional activity of the tissue. The muscles are surrounded by a layer of connective tissue-endomysium, and the bundles - perimysium, between the collagen fibers of which adipocytes are located (fig. 1). 
Table 6. Content of certain micro- and macronutrients in rabbit meat in the experiment $(n=3)$.

\begin{tabular}{|c|c|c|c|c|c|c|c|}
\hline & $\mathrm{N}, \mathrm{mg}$ & $\mathrm{Ca}, \mathrm{mg}$ & $\mathrm{Mg}, \mathrm{mg}$ & $\mathrm{I}, \mathrm{mcg} / \mathrm{kg}$ & $\mathrm{Se}, \mathrm{mg} / \mathrm{kg}$ & $\mathrm{Co}, \mathrm{mg}$ & $\mathrm{Cu}, \mathrm{mg}$ \\
\hline \multicolumn{8}{|c|}{$1^{\text {st }}$ group } \\
\hline $\mathrm{X} \pm \mathrm{S}_{\mathrm{X}}$ & $\begin{array}{c}3.53 \\
\pm 0.0354\end{array}$ & \begin{tabular}{|c|}
0.027 \\
$\pm 0.0014 * *$
\end{tabular} & $\begin{array}{c}0.0175 \\
\pm 0.0018\end{array}$ & $\begin{array}{c}14.7 \\
\pm 2.1920\end{array}$ & $\begin{array}{c}0.0605 \\
\pm 0.001 * * *\end{array}$ & $\begin{array}{c}0.0065 \\
\pm 0.0004\end{array}$ & $\begin{array}{c}0.5345 \\
\pm 0.0209^{*}\end{array}$ \\
\hline $\mathrm{C}_{\mathrm{v}}, \%$ & 1.4 & 7.4 & 14.3 & 21.1 & 2.5 & 7.7 & 5.5 \\
\hline \multicolumn{8}{|c|}{$2^{\text {nd }}$ group } \\
\hline $\mathrm{X} \pm \mathrm{Sx}$ & $\begin{array}{c}3.68 \\
\pm 0.05 *\end{array}$ & $\begin{array}{c}0.0145 \\
\pm 0.0004 \\
\end{array}$ & $\begin{array}{c}0.015 \\
\pm 0.001\end{array}$ & $\begin{array}{c}95.7 \\
\pm 7.071 * * \\
\end{array}$ & $\begin{array}{c}0.0645 \\
\pm 0,0103\end{array}$ & $\begin{array}{c}0.014 \\
\pm 0.0042\end{array}$ & $0.4855 \pm 0.0534$ \\
\hline $\mathrm{C}_{\mathrm{v}}, \%$ & 1.9 & 3.4 & 13.3 & 10.4 & 22.5 & 42.9 & 15.6 \\
\hline \multicolumn{8}{|c|}{$3^{\text {rd }}$ group } \\
\hline $\mathrm{X} \pm \mathrm{S}_{\mathrm{X}}$ & $3.63 \pm 0.05$ & $\begin{array}{c}0.0155 \\
\pm 0.0004 \\
\end{array}$ & $\begin{array}{c}0.0145 \\
\pm 0.0004 \\
\end{array}$ & $\begin{array}{c}49.15 \\
\pm 5.20^{* *} \\
\end{array}$ & $\begin{array}{c}0.0435 \\
\pm 0.0004 \\
\end{array}$ & $\begin{array}{c}0.0185 \\
\pm 0.0032 * \\
\end{array}$ & $0.4125 \pm 0.0343$ \\
\hline $\mathrm{C}_{\mathrm{v}}, \%$ & 2.1 & 3.2 & 3.4 & 15.0 & 1.1 & 24.3 & 11.8 \\
\hline
\end{tabular}

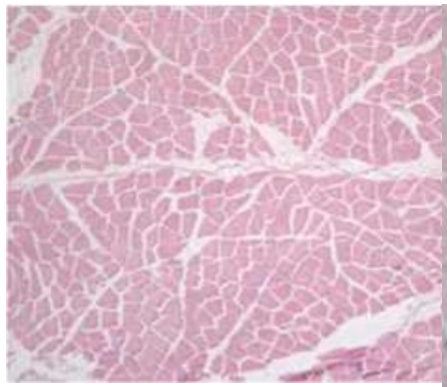

A. $1^{\text {st }}$ group
B. $2^{\text {nd }}$ group

\section{C. $3^{\text {rd }}$ group}

Fig. 1. Histological section of the thigh muscle of rabbits in the experiment on the use of liposomal form of antioxidants with organic iodine content.

In the experimental groups, there was an increase in the number of muscle fibers by $68.0-78.0 \%(\mathrm{p}<0.05-0.01)$, which is reflected in an increase in the ratio of muscle and connective tissue. Diameter of the muscle fiber in the experimental groups, also, was a decrease by $13.1-17.3 \%(\mathrm{p}<0.05-\mathrm{p}<0.05)$. This fact indicates a finer structure of muscle fibers in young animals of experimental groups (table 7).

Table 7. Morphometric indicators of muscle tissue of control and experimental groups of rabbits.

\begin{tabular}{|c|c|c|c|}
\hline Indicator & $1^{\text {st }}$ group & $2^{\text {nd }}$ group & $3^{\text {rd }}$ group \\
\hline Number of muscle fibers per $100 \mathrm{pm}^{2}$ & $32.56 \pm 1.38$ & $55.00 \pm 2.98^{*}$ & $57.97 \pm 1.58^{* *}$ \\
\hline The percentage of muscle & $70,67 \pm 3.33$ & $76.33 \pm 2.33$ & $78.35 \pm 1.87$ \\
\hline The percentage of stroma & $29.67 \pm 3.67$ & $23.67 \pm 2.33$ & $21.96 \pm 2.04$ \\
\hline Diameter of the muscle fiber, pm & $33.55 \pm 1.05$ & $29.16 \pm 1.05^{*}$ & $27.67 \pm 0.87^{*}$ \\
\hline Endomysium thickness, pm & $6.30 \pm 0.23$ & $6.17 \pm 0.33$ & $6.04 \pm 0.25$ \\
\hline Perimysium thickness, pm & $19.19 \pm 1.11$ & $24.03 \pm 1.97$ & $25.62 \pm 1.45$ \\
\hline
\end{tabular}

Changes in the connective tissue component affect primarily the perimysium having little effect on the shell of muscle fibers. In perimysium, an increase in the accumulations of fat cells, particularly around the neurovascular bundles is also observed (fig. 1B). 


\section{Conclusions}

The study of the effect of antioxidants in a liposomal form containing organic iodine allowed to get the following results. Young rabbits safety of in the experimental groups was higher by 8.0 and 4.0 percent than in the control one. Live weight at the age of 92 days of Young rabbits of experimental groups was higher by 1.3 and 5.2 percent in comparison with the control group of animals. Organic iodine affected the content of thyroid hormones. The significant increase of thyroxine in the experimental groups was in $2^{\text {nd }}$ one by $6.7 \%$ and in $3^{\text {rd }}$ one by $8.9 \%(p<0.05)$. In the third group, the trend of increase the total protein in blood serum is reliable: in comparison with the control, it increases by 3.39 units $(p<0.05)$. This trend continues and in albumin levels by 3.58 units $(\mathrm{p}<0.05)$. No fundamental regularities were found in the content of liver enzymes. There was an significant increase in creatinine in young rabbits of both experimental groups by 20.51-28.89 units $(p<0.05)$. There was a significant excess of iodine content in meat in the $2^{\text {nd }}$ group of rabbits by 81.0 mcg and in animals of $3^{\text {rd }}$ group by $234.1 \%$. the difference is significant in both cases $(p<0.05)$. An increase of number of muscle fibers in both experimental groups by 68.0 and 78.0 percent $(p<0.05-0.01)$ was noted. However, the tendency of percentage of muscle goes to increase by almost by $6-7 \%$. But the diameter of the muscle fiber of experimental animals reliably lower on $13.1(p<0.05)-17.3 \%(p<0.05)$. Thus, the animals of the experimental groups formed the meat with a more delicate structure and an increased content of valuable parts are the muscle and fat tissue.

The experiments were carried out in the framework of research work, state registration number AAAA-A16-116022610122-2.

\section{References}

1. Li S, Zhao M, Jiang T, Lv W, Gao Sh, Zhou Yu and Miao Z 2018 Growth performance and antioxidant status of growing rabbits fed on diets supplemented with Eucommia ulmoides leaves World Rabbit Science 26(1) 35-41 doi: https://doi.org/10.4995/wrs.2018.7864

2. Ayodele S, Oloruntola O D and Agbede J O 2016 Effect of Alchornea cordifolia leaf meal inclusion and enzyme supplementation on performance and digestibility of rabbits Wabbit Science 24(3) 201-216 doi: https://doi.org/10.4995/wrs.2016.3933

3. Valenzuela-Grijalva, Pinelli-Saavedra N A, Muhlia-Almazan A, Domrnguez-Diaz D and Gonzalez-Rms H 2017 Dietary inclusion effects of phytochemicals as growth promoters in animal production Journal of Animal Science and Technology 58 6-8 doi: https://doi.org/10.1186/s40781-017-0133-9

4. Oloruntola O D, Ayodele S O, Adeyeye S A and Agbede J O 2018 Performance, haemato-biochemical indices and antioxidant status of growing rabbits fed on diets supplemented with Mucuna pruriens leaf meal World Rabbit Science 26(4) 277-285 doi: https://doi.org/10.4995/wrs.2018.10182.

5. Tawfeek S, Hassanin K M A and Youssef I M I 2014 The effect of dietary supplementation of some antioxidants on performance, oxidative stress, and blood parameters in broilers under natural summer conditions Journal of World' Poultry Research 4 10-19

6. Nijveldt R J, van Nood E, van Hoorn D E, Boelens P G, van Norren K and van Leeuwen P A 2001 Flavonoids: a review of probable mechanisms of action and potential applications American Journal of Clinical Nutrition 74 418-425 doi: 


\subsection{3/ajcn/74.4.418}

7. Rahman K 2007 Studies on free radicals, antioxidants, and cofactors Clinical Interventions in Aging 2(2) 219-236 doi: http://dx.doi.org/10.4236/fns.2013.46083

8. Marzoni M, Chiarini R, Castillo A, Romboli I, Marco M D and Schiavone A 2014 Effects of dietary natural antioxidant supplementation on broiler chicken and Muscovy duck meat quality Achille Schiavone Animal Science Papers and Reports 32(4) 359368

9. Khaligh F, Sadeghi G, Karimi A and Vaziry A 2011 Evaluation of different medicinal plants blends in diets for broiler chickens Journal of Medicinal Plants Research 5 1971-1977 doi: https://doi.org/10.5897/JMPR.9000622

10. Castillo-Lopez R, Gutierrez-Grijalva E P, Leyva-Lopez N, Lopez-Marti'nez L X and Heredia J B 2017 Natural Alternatives to growth-promoting antibiotics (GPA) in animal production The Journal of Animal \& Plant Sciences 349-359

11. Adaszynska-Skwirzynska M and Szczerbinska D 2017 Use of essential oils in broiler chicken production - a review Annals of Animal Science 17(2) 317-335 doi: 10.1515/aoas-2016-0046

12. Suntres Z E 2011 Liposomal Antioxidants for Protection against Oxidant-Induced Damage Journal of Toxicology 1-16 doi: 10.1155/2011/152474.

13. Akbarzadeh A, Rezaei-Sadabady R, Davaran S, Joo S W, Zarghami N, Hanifehpour Y, Samiei M, Kouhi M and Nejati-Koshki K 2013 Liposome: classification, preparation, andapplications Nanoscale Research Letters 1029 doi: 10.1186/1556-276X-8-102

14. Ulit'ko V E, Pykhtina L A, Erisanova O E and Gulyaeva L Yu 2017 Ecological and Incubation Properties of Laying Hens' Eggs when Using Antioxidant Supplement in the Ration Research Journal of Pharmaceutical Biological and Chemical Sciences 8(2) 2077-2082

15. Pashtetsky V, Il'yazov R, Ostapchuk P, Kuevda T, Zubochenko A and Zubochenko D 2019 Influence of iodine based exogenous antioxidants on the productive indicators of laying hens IOP Conf. Ser.: Earth Environ. Sci. 341012013 doi: 10.1088/1755$1315 / 341 / 1 / 012013$

16. Pankiv V I 2014 Problems of combined selenium and iodine deficiency in the development of thyroid pathology International journal of endocrinology 5 №61 7580 (In Russ.)

17. Rodionova L V, Prudnikova N V, Popova L G, Lebedev V F, Shurigina I A, Shurigin M G, Jakunina N P and Lepekhova S A 2013 Dynamics of thyroid hormone while modeling of a standard fracture in rabbits Acta Biomedica Scientifica 2(2) 161-166 (In Russ.)

18. Sviridonova M A and Fadeyev V V 2008 Clinical Significace of Thyrotropin Variability Clinical and experimental thyroidology 4(4) 16-24 (In Russ.)

19. Fadeev V V 2004 Standards of the TTG level: do we need changes? Clinical thyroidology 3 5-9 (In Russ.)

20. Hansen P S, Brix T H and Iachine I 2007 Genetic and environmental interrelations between measurements of thyroid function in a healthy Danish twin population Am. J. Physiol. Endocrinol. Metab. 292 765-770

21. Hansen P S, Brix Th H, Sørensen Th I A, Kyvik K O and Hegedüs L 2004 Major Genetic Influence on the Regulation of the Pituitary Thyroid Axis: A Study of Healthy Danish Twins J. Clin. Endocrinol. Metab. 89(3) 1181-1187 doi: 10.1210/jc.2003031641 
22. Yagmurov E R, Kozlov G V, Pushkarev M A 2017 Lipase purification: the review of conventional and novel methods Journal of Hygienic Engineering and Design 20 6069 